\title{
Estimating worldwide costs of premature mortalities caused by COVID-19
}

\author{
Jaime A. Teixeira da Silva \\ Independent Researcher, Miki-cho, Japan, and \\ Panagiotis Tsigaris \\ Thompson Rivers University, Kamloops, Canada
}

\begin{abstract}
Purpose - The purpose of this paper is to provide an estimate of the costs of premature mortality caused by the COVID-19 pandemic.

Design/methodology/approach - Using COVID-19 pandemic-derived mortality data for November 9, 2020 (globally 1,303,215 deaths) and applying a country-based value of statistical life (VSL), the worldwide cost of premature mortality was assessed. The cost was assessed based on income groups until November 9, 2020 and projected into the future until March 1, 2021 using three scenarios from the Institute for Health Metrics and Evaluation (IHME).

Findings - The global cost of premature mortality is currently estimated at Int $\$ 5.9$ trillion. For the highincome group, the current estimated cost is Int $\$ \$ 4.4$ trillion or $\$ 3,700$ per person. Using IHME projections until March 1, 2021, global premature mortality costs will increase to Int $\$ 13.7$ trillion and reach Int $\$ 22.1$ trillion if policies are relaxed, while the cost with $95 \%$ universal masks is Int $\$ 10.9$ trillion. The richest nations will bear the largest burden of these costs, reaching $\$ 15,500$ per person by March 1, 2021 if policies are relaxed.

Originality/value - The cost of human lives lost due to the pandemic is unprecedented. Preparedness in the future is the best policy to avoid many premature deaths and severe recessions in order to combat pandemics.
\end{abstract}

Keywords COVID-19, Premature mortality, Preparedness, Transfer method approach,

Value of statistical life (VSL)

Paper type Short report

\section{Introduction}

Economists view the value of life, not as a price of a human life but to assess the value of mortality risks humans place when considering trading off risk of dying and money [1-3]. The "Value of a Statistical Life" (VSL) is not about a particular death but about a statistical death. The VSL is often used to assess regulatory and global health policies which result in lives saved. Examples include workplace safety measures, pollution reduction policies, universal masks for protection from viruses such as SARS-CoV-2 and measurements of the cost associated with people dying prematurely due to increased risks [2]. Saving lives can only be achieved by implementing costly policy-based measures and benefits emerge which are equivalent to the benefits of saving lives. Alternatively, not implementing such policies

(C) Jaime A. Teixeira da Silva and Panagiotis Tsigaris. Published in Journal of Health Research. Published by Emerald Publishing Limited. This article is published under the Creative Commons Attribution (CC BY 4.0) licence. Anyone may reproduce, distribute, translate and create derivative works of this article (for both commercial and non-commercial purposes), subject to full attribution to the original publication and authors. The full terms of this licence may be seen at http://creativecommons.org/licences/by/4.0/ legalcode

Author contributions. The authors, who are co-corresponding authors, contributed equally to the intellectual discussion underlying this paper, literature exploration, writing, reviews and editing, and accept responsibility for its content.

Conflicts of interest. The authors declare no conflicts of interest.

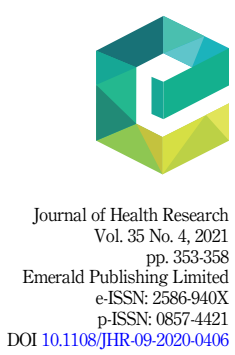


JHR

35,4

can be seen as a cost of premature mortalities. Cutler and Summers [4] estimated the cost of premature mortality due to the COVID-19 pandemic at US\$4.375 trillion for the US using an estimated cumulative 650,000 premature deaths throughout 2021 and using a conservative VSL of US $\$ 7 \mathrm{~m}$ per life, rather than the US $\$ 10 \mathrm{~m}$ figure commonly used for assessing issues and regulations.

As an illustration, suppose a community of one million people becomes vulnerable in the future from a potential deadly virus pandemic, like COVID-19, A forward-looking community can decide to allocate funds, which would otherwise be used for other problems, to be better prepared for such a dreadful event, which would reduce the risk of someone dying prematurely. If such preparedness reduces risk and saves one life out of one million vulnerable people (i.e. a $0.0001 \%$ reduction in risk), and we ask those people how much they are willing to pay to reduce the risk marginally from dying prematurely, and if each person is willing pay on average US $\$ 10$, then the VSL is $10 / 0.000001$ or US\$10m. Simply stated, if each person in a population of one million people is willing to pay US $\$ 10$ to save a "statistical" life, the benefit of saving a life would be US $\$ 10$ million. If 20,000 lives are saved from dying prematurely due to effective preventive measures, then the total benefits of such actions would be US $\$ 200$ billion. By not being prepared, 20,000 premature deaths would occur, costing the community US\$200bn. There was ample warning that the globe should have been prepared for a future pandemic [5, 6], but clearly insufficient preparations were made, resulting in a cost that we attempt to estimate in this paper.

The VSL has been computed using the stated preference or willingness to pay approach to avoid the risk of premature death, as illustrated above in the hypothetical example, but there are other methods, such as the human capital approach, which attempts to place a value based on an individual's lost future earnings, or the hedonic wage approach, which extrapolates the wage-risk trade-off in the labor market [7]. However, in this paper, we use the transfer function method [8], which is discussed in the next section.

\section{Methods}

We examined 142 nations of four income groups according to the World Bank classification (Suppl. Table 1). In order to find the VSL for each nation, we used the Viscusi and Masterman transfer function method [8] with an assumed VSL income elasticity of unity, which implies that the VSL of a nation is proportional to its gross domestic product (GDP) per person. To arrive to the VSL of other nations, we used as the baseline, the USA's VSL value of US $\$ 9.631 \mathrm{~m}$ per life saved, as per Viscusi and Masterman [8], and a GDP per capita in purchasing power parity constant 2017 international dollars (Int\$) in 2019 at Int\$62,683, as per the World Bank (see supplementary file for data definition and sources). The VSL of a nation is proportional to the USA's VSL, where the factor of proportionality is the ratio of GDP per capita of the nation studied relative to the US GDP per capita. Hence, nations that have a higher GDP per capita than the US will have a higher VSL and vice versa. Thus the cost of premature mortality for $N$ nations is then the sum of the VSL times the number of deaths given by:

$$
\text { Cost }=\sum_{i=1}^{N} \text { Deaths }_{i} * \mathrm{VSL}_{i}=\sum_{i=1}^{N} \text { Deaths }_{i} * \mathrm{VSL}_{\mathrm{USA}} \frac{\mathrm{GDP} \text { per capita }}{\mathrm{GDP}_{i}}
$$

The premature mortality costs were also estimated until March 1, 2021 using IHME projections under their three scenarios [9]. The first scenario is known as "current projections", which are based on social distancing policies being relaxed but re-imposed for six weeks when daily deaths reach eight per million people. The second scenario, "mandate easing", is projections based on nations relaxing their social distancing policies and not reimposing mandates, when daily deaths exceed the above threshold. The final scenario, 
"universal masks", examines the impact of universal masks when $95 \%$ of the population wears masks publicly (e.g. Singapore) and mandates, as for the first scenario, are also imposed. The IHME, which uses a deterministic SEIR (susceptible, exposed, infectious and recovered) epidemiological model to conduct projections, found that 130,000 lives can be saved with universal masks relative to the "current projections" path [10].

\section{Results}

Cost of premature mortalities until November 9, 2020

As expected, the majority of deaths are in the high-income group followed closely by the emerging economies. Among the 142 countries with COVID-19-reported deaths, high-income countries accounted for $43 \%$ of these deaths and when the middle upper-income nations were included, the percentage increased to $83 \%$. The cost to high income nations is $7.6 \%$ of the $2019 \mathrm{GDP}$ or Int $\$ 3,700$ per person. For the emerging nations (middle upper income), the cost is $3.1 \%$ of GDP or Int $\$ 512$ per person. The low-income nations are least affected by COVID-19, with a cost of $0.2 \%$ of GDP or Int $\$ 4$ per person (Table 1). Supplementary Table 2 shows that the top 20 nations accounted for $83 \%$ of the total deaths and $90 \%$ of the cost of human deaths. The cost is estimated at Int $\$ 5.9$ trillion with the US's cost estimated at Int $\$ 2.3$ trillion followed by the UK (Int $\$ 464 \mathrm{bn})$.

\section{Projected cost of premature mortalities to March 1, 2021 under the three scenarios}

Costs were also assessed using three different scenario projections from the IHME [9]. Supplementary Table 3 shows the projected estimated total deaths in 142 nations by March 1 , 2021 under the "current projections" scenario at $2.7 \mathrm{~m}$ people $(95 \%$ uncertainty interval $(\mathrm{UI})=[2.2 ; 3.4])$. The cost of premature mortality will increase from Int $\$ 5.9$ trillion on November 9, 2020 to more than double at Int13.7\$ trillion by March 1, 2021. Rich nations will suffer the most at a cost of Int $\$ 10.7$ trillion (18\% of GDP). The expected death toll in the USA by March 1, 2021 is predicted to be 438,940 at a cost of Int $\$ 4.23$ trillion. This result is more pessimistic than the estimated cost made by Cutler and Summers [4]. Supplementary Table 4 shows 2.2 million deaths under a universal mask scenario $(95 \% \mathrm{UI}=[1.8 ; 2.6])$. This means that 554,487 lives can be saved, including 68,200 US lives if universal masks are implemented relative to the "current projections" scenario for the 142 nations. The cost is projected to be Int $\$ 10.9$ trillion with universal masks, but with mandate easing, costs will increase to Int $\$ 22.1$ trillion by March 1, 2021 (Supplementary Table 5) based on a projected death toll of four million $(95 \%$ UI $=[2.9 ; 5.3])$. Hence, the value of having universal masks relative to the

\begin{tabular}{|c|c|c|c|c|c|c|c|c|c|}
\hline $\begin{array}{l}\text { Income } \\
\text { type }\end{array}$ & $\begin{array}{l}\text { GDP } \\
\text { per } \\
\text { capita } \\
2019\end{array}$ & $\begin{array}{l}2019 \\
\text { population } \\
\text { (in billions) }\end{array}$ & $\begin{array}{l}\text { Age } \\
\text { over } \\
65, \\
\%\end{array}$ & Deaths & $\begin{array}{c}\% \text { Of } \\
\text { total } \\
\text { deaths }\end{array}$ & $\begin{array}{c}\text { \# Of } \\
\text { nations }\end{array}$ & $\begin{array}{l}\text { Cost of } \\
\text { premature } \\
\text { deaths (in } \\
\text { billions of } \\
\text { Int\$s) }\end{array}$ & $\begin{array}{l}\text { Cost } \\
\text { as a } \\
\% \text { of } \\
2019 \\
\text { GDP }\end{array}$ & $\begin{array}{c}\text { Cost } \\
\text { per } \\
\text { person }\end{array}$ \\
\hline High & 48,571 & 1.1826 & 15.42 & 543,220 & 43.13 & 49 & 4379.7 & 7.63 & 3,704 \\
\hline $\begin{array}{l}\text { Middle } \\
\text { upper }\end{array}$ & 16,810 & 2.5745 & 9.25 & 503,385 & 39.97 & 41 & 1319.4 & 3.05 & 512 \\
\hline $\begin{array}{l}\text { Middle } \\
\text { lower }\end{array}$ & 6,464 & 2.8939 & 5.04 & 206,412 & 16.39 & 31 & 240.6 & 1.29 & 83 \\
\hline $\begin{array}{l}\text { Low } \\
\text { Total }\end{array}$ & 1,910 & $\begin{array}{l}0.5414 \\
7.1923\end{array}$ & 3.08 & $\begin{array}{r}6,337 \\
1,259,354\end{array}$ & $\begin{array}{r}0.50 \\
100.00\end{array}$ & $\begin{array}{r}21 \\
142\end{array}$ & $\begin{array}{r}2.2 \\
5941.8\end{array}$ & 0.21 & 4 \\
\hline
\end{tabular}

Note(s): On November 9, 2020, there were a total of 1,303,215 deaths, as per the IHME
Premature mortalities caused by COVID-19

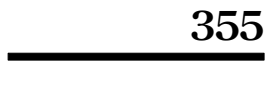


JHR

35,4

"current projections" scenario for the November 9, 2020 to March 1, 2021 period is Int $\$ 2.8$ trillion. Table S6 shows the benefits of having universal masks relative to the "current projections" scenario among the top 10 nations. Germany was ranked first as it started from a lower baseline of mask use (around 50\%) and a high VSL. When the top 10 nations were ranked by lives saved, only four were high-income nations, but when they were ranked in terms of valuation of the benefits of saving lives, nine were high-income nations. The IHME projections were last updated on November 12, 2020, and are expected to change often as new information arrives. We also report shorter-term IHME projections for January 1 and February 1, 2021 (Supplementary Tables S7-S12).

\section{Discussion}

In this study, costs of premature mortality caused by the COVID-19 pandemic were estimated until March 1, 2021 using IHME projections. Using mortality data for November 9, 2020 (globally 1,303,215 deaths), we estimated the cost of not being prepared for such a pandemic at approximately Int $\$ 5.9$ trillion. Rich nations suffer the most from not being prepared to handle COVID-19, although emerging nations now have a growing representation. Poor and underdeveloped nations might have not been as impacted by the virus most likely because of greater isolation from the rest of the world and a very low percentage of people aged 65+ (Table 1).

A recent study estimated the cost of a future major epidemic or pandemic, including the valuation of lives lost, at 720,000 deaths per year at an annual loss of US $\$ 0.5$ trillion per year equivalent to a cost of $0.6 \%$ of global income per year [11]. In a cross-sectional study of 121 nations, evidence showed that a delay in policy enactment, such as international travel restrictions and testing policies, led to a higher fatality rate relative to not delaying such mandates [12].

The cost of lockdowns is two-fold: lives lost and economic losses. According to the International Monetary Fund (IMF), the world economy is expected to contract by $4.4 \%$ in 2020 from a 3.3\% growth projection in 2020 in the absence of COVID-19 as per the January 9, 2020 world economic outlook report, as a direct consequence of COVID-19 [13, 14]. This is equivalent to Int $\$ 10$ trillion loss (i.e. $7.7 \%$ of Int $\$ 130$ trillion world GDP) for 2020; more losses are expected in 2021 and in future years relative to the absence of the pandemic [4]. The majority of 2020 economic losses were observed in advanced economies that were not prepared for COVID-19. South Korea was prepared, innovatively avoiding a total lockdown of its economy [15]. The IMF projected South Korea's GDP to contract by $2.1 \%$ in 2020 from $2 \%$ growth in 2019, while the US and Euro Area were projected to have an economic downturn of 8 and $10.2 \%$ in 2020 from 1.7 and $1.3 \%$ growth in 2019 , respectively [14].

Being prepared for future pandemics is a worthy investment since the cost of not acting will be very high. The world should have been sufficiently prepared for a forthcoming pandemic [5, 6], but was not. With each new life taken by COVID-19, economic, social and psychological costs also increase, but these could be tempered by sufficient timely planning and robust policies to deal with the resurgence of this pandemic or with the emergence of another pandemic $[16,17]$.

\section{Limitation of this study}

There are a number of shortcomings of this global cost assessment. First, the transfer method approach [8] arrives at VSL values of non-US nations assuming unitary income elasticity, but some evidence indicates that the income elasticity of VSL is not constant [18]. Values might differ using country-specific data instead of relying on the transfer function approach [8]. Another limitation is that we used a population average VSL instead of a constant value per statistical life-year (VSLY), whereby money is substituted for increasing life expectancy, or a 
VSL that peaks at middle age, thereby placing less weight on young and older age groups. The latter two methods would reduce the benefits of policies to contain the pandemic [19]. However, deaths are most likely underreported, so this underestimates the global cost of premature mortality [20]. The IHME projections might not be realized, as they are based on specific values assigned to parameters of the SEIR model and do not include economics into epidemiological models [21]. Finally, none of these predictions factor in the possibility of a successful vaccine.

\section{References}

1. Rice DP, Cooper BS. The economic value of human life. Am J Public Health Nations Health. 1967 Nov; 57(11): 1954-66.

2. Kniesner TJ, Viscusi WK. The value of a statistical life. Forthcoming. Oxford Research Encyclopedia of Economics and Finance. Vanderbilt Law Research Paper No. 19-15. [cited 2020 November 19]. Available at: https://ssrn.com/abstract $=3379967$.

3. Schelling TC. The life you save may be your own. In: Chase SB, editor. Problems in public expenditure analysis. Washington, DC: The Brookings Institution; 1968. p. 127-61.

4. Cutler DM, Summers LH. The COVID-19 pandemic and the $\$ 16$ trillion virus. JAMA. 2020 Oct; 324(15): 1495-6. doi: 10.1001/jama.2020.19759.

5. Osterholm MT. Preparing for the next pandemic. N Engl J Med. 2005 May; 352(18): 1839-42. doi: 10.1056/NEJMp058068.

6. Gates B. The next epidemic-lessons from Ebola. N Engl J Med. 2015 Apr; 372(15): 1381-4. doi: 10. 1056/NEJMp1502918.

7. Witvorapong N, Komonpaisarn T. The value of a statistical life in Thailand: evidence from the labour market. J Consum Policy. 2020; 43(3): 491-518. doi: 10.1007/s10603-019-09431-2.

8. Viscusi WK, Masterman CJ. Income elasticities and global values of a statistical life. J Benefit Cost Anal. 2017; 8(2): 226-50. doi: 10.1017/bca.2017.12.

9. Institute for Health Metrics and Evaluation [IHME]. COVID-19 projections. [cited 2020 November 19]. Available at: http://www.healthdata.org/covid/faqs\#Scenarios.

10. IHME COVID-19 Forecasting Team. Modeling COVID-19 scenarios for the United States. Nat Med. 2021 Jan; 27: 94-105. doi: 10.1038/s41591-020-1132-9 (in press).

11. Fan VY, Jamison DT, Summers LH. Pandemic risk: how large are the expected losses?. Bull World Health Organ. 2018 Feb; 96(2): 129-34. doi: 10.2471/blt.17.199588.

12. Teixeira da Silva JA, Tsigaris P. Policy determinants of COVID-19 pandemic-induced fatality rates across nations. Publ. Health. 2020 Oct; 187: 140-2. doi: 10.1016/j.puhe.2020.08.008.

13. International Monetary Fund. World economic outlook: a long and difficult ascent. [cited 2020 November 19]. Available at: https:/www.imf.org/en/Publications/WEO/Issues/2020/09/30/worldeconomic-outlook-october-2020.

14. International Monetary Fund. World economic outlook: tentative stabilization, sluggish recovery? [cited 2020 November 19]. Available at: https://www.imf.org/en/Publications/WEO/Issues/2020/01/ 20/weo-update-january2020.

15. Park J, Chung E. Learning from past pandemic governance: early response and public-private partnerships in testing of COVID-19 in South Korea. World Dev. 2021 Jan; 137: 105198. doi: 10. 1016/j.worlddev.2020.105198.

16. Gates B. Responding to covid-19 - a once-in-a-century pandemic?. N Engl J Med. 2020 Apr; 382(18): 1677-9. doi: 10.1056/NEJMp2003762.

17. Khubchandani J, Jordan TR, Yang YT. Ebola, Zika, Corona...What is next for our world?. Int J Environ Res Public Health. 2020 May; 17(9): 3171. doi: 10.3390/ijerph17093171.

Premature mortalities caused by COVID-19 
JHR 35,4

18. Barbier EB, Czajkowski M, Hanley N. Is the income elasticity of the willingness to pay for pollution control constant?. Environ Resour Econ. 2017; 68(3): 663-82. doi: 10.1007/s10640-0160040-4.

19. Robinson LA, Sullivan R, Shogren JF. Do the benefits of COVID-19 policies exceed the costs? Exploring uncertainties in the age-VSL relationship. Risk Anal. doi: 10.1111/risa.13561 (in press).

20. Lau H, Khosrawipour T, Kocbach P, Ichii H, Bania J, Khosrawipour V. Evaluating the massive underreporting and undertesting of COVID-19 cases in multiple global epicenters. Pulmonology. doi: 10.1016/j.pulmoe.2020.05.015 (in press).

21. Murray EJ. Epidemiology's time of need: COVID-19 calls for epidemic-related economics. J Econ Perspect. 2020; 34(4): 105-20. doi: 10.2307/26940892.

\section{Appendix}

The supplementary material is available at: https://www.researchgate.net/publication/347901656

\section{Corresponding author}

Jaime A. Teixeira da Silva can be contacted at: jaimetex@yahoo.com and Panagiotis Tsigaris can be contacted at: ptsigaris@tru.ca

For instructions on how to order reprints of this article, please visit our website:

www.emeraldgrouppublishing.com/licensing/reprints.htm

Or contact us for further details: permissions@emeraldinsight.com 